2. World Association for the Advancement of Veterinary Parasitology (W.A.A.V.P.) second edition: Guidelines for evaluating the efficacy of parasiticides for the treatment, prevention and control of flea and tick infestations on dogs and cats. $-14 \mathrm{p}$.

3. Halat V. F. Parazytolohiya ta invaziyni khvoroby tvaryn / V. F. Halat, A. V. Berezovs'kyy, M. P. Prus, N. M. Soroka. - K., Urozhay, 2009. - 363 s. (in Ukrainian).

Рецензент - І. Д. Юськів, д. вет. н., професор кафедри паразитології та іхтіопатології ЛНУВМБ імені С. З. Гжицького.

doi: 10.36359/scivp.2019-20-2.37

\title{
"DEMOGED-FORTE" VETERINARY MEDICINAL PRODUCT IN COMBATING ECTOPARAZITOSIS IN DOGS AND CATS
}

\author{
Enciu Valeriu \\ State Agrarian University of Moldova. \\ 42, Mirceşti Street, Chişinău, MD 2049, Moldova
}

Parasitic arachnoses, through their serious evolution, have anthropozoonotic characters with economic, sanitary and social implications. Infestation with arachnids diminishes considerably the quality of life of domestic animals, causing them metabolic diseases, scratching, stress, allergies and leads to the development of bacterial dermatoses. Fipronil is an acaricidal and stable remedy that lasts longer. The purpose of this study was the control of the efficacy of acaricide of the DemogedForte pharmaceutical product in order to combat the ectoparasites in cats and dogs, conditioned by the company Euro Prime Farmaceuticals LLC. The product is very effective in combating sarcoptoses and notoendrosis (98-100\%) in dogs and cats. In the treatment of otodectoses, the product demonstrated an efficacy of $99 \%$, and in demodicoses was found a result of about 90-92\%. Thus, Demoged-Forte independently, without complexs therap, demonstrated a high efficacy in the treatment of sarcoptoses, notoendrosis, otodectoses and demodicoses, ranging between 92-99\%, which confirms that we can treat animals without putting their lives in danger.

Keywords: ARACHNOSES, FIPRONIL, DIFLUBENZURON, TESTING, TREATMENT, EFFICACY.

Ectoparasites are widespread in the environment, causing a number of common parasitosis for humans and animals. The diseases that the ectoparasites produce or transmit are divided into: bladder, hives, venom, irritants, invaders, tissues, vectors, the direct pathogenic role for them being the sting [6, 8].

By their serious evolution, parasitic arachnoses have anthropozoonotic characters, having economic, health and social implications (sarcoptooses, psoroptooses, demodecoses, tick paralysis).

Arachnid infestation greatly diminishes the life quality of pets, attacking them, causing metabolic diseases, scratching, stress and allergies. By giving access to infections, ectoparasites disrupt the barrier function of the common integument leading to the development of bacterial dermatodoses. Moreover, by their role as a vector, many ectoparasites can mechanically transmit or be intermediate hosts for other pathogens (bacteria, viruses, protozoa, parasites). [3, 4]. 
For veterinary dermatological practice, arachnosis is of particular importance: sarcoptoosis, notoedrosis, otodectosis, demodicosis. These diseases affect both dogs and cats, but with a different degree of infestation. Thus, sarcoptoosis and demodicosis are more common for dogs, and notohedrosis and otodectosis for cats. [2, 7].

Sarcopoptosis or sarcoptic scab is highly contagious, with zoonotic potential, itching, frequently encountered for dogs. The causative agent is the Sarcoptes canis mite. The sarcophagi belong to the permanent ectoparasites, because they live on the surface of the skin and in the intraepidermal galleries. Outside the host, the parasites cannot survive more than 15-17 days. The transmission of the disease is direct, through tritonimfis. The incubation period varies from 2-8 weeks. Depending on the age of the dog both clinical appearance, as well as the evolution of the disease may have different manifestations [2,3].

Demodicosis or demodecal scab affects many species of animals, including dogs and cats. The causative agent in dogs is Demodex canis, and in cats Demodex cati. The demodecas parasitize the hair follicles and sebaceous glands. In the serious phases of the invasion, they enter the lymph nodes, intestine, liver, spleen, kidneys. Demodels are permanent parasites and the biological cycle takes place on the same host. Demodecia affects young dogs, 3-12 months old. The source of parasites is the sick animals and carriers. Since demodecas have no free phase, outside the host organism, there are no vectors. The optimal time of transmission is the neonatal period, during the first hours of life, during feeding or through direct contact with their mothers $[1,6,7,9]$.

Notohedrosis or nothedral scab is a chronic parasitic disease that manifests through skin inflammation, scratching, itching and hair loss. The causative agent is the mite Notoedres cati, which parasites the head region in cats through galleries dug in the epidermis, irritating the nerve endings. It is possible to be transmitted to humans, with a benign evolution, the infestation being unpleasant. Head localization and extension in the surrounding areas, and contagiousness and intense itching lead to the establishment of the clinical diagnosis. The prognosis is favorable when the disease is diagnosed in the early stage [10].

Otodectosis or otodectic scab is a chronic invasive disease, specific to cats, dogs and other fur animals. The causative agent is Otodectes cynotis. The duration of the biological cycle is about 3 weeks and it causes otitis in 10\% of dogs and 30-50\% in cats, the parasitis feeds on lymph and blood of the host and causes sensitization of the animal body by introducing mite antibodies $[2,4,12]$.

In the absence of prophylactic means with direct action on the causal agents, it is recommended to use acaricide remedies with a strong and stable effect of longer duration. Such remedy can be fipronil, which possesses both acaricidal and insecticidal qualities [7, 10]. The mechanism of action of fipronil, which is part of the Demoged-Forte product, consists in blocking GABA (gamma-amino-butyric acid) at the level of neuromuscular synapses, which leads to nerve impulse disturbance. As a result, hyperexcitation of the nerves and muscles of the insects occurs, thus causing their death [7].

Definihydrramine hydrochloride is a blocker of histamine H1 receptors, which possess antihistamine, cholinolytic, anti-inflammatory and topical anesthesia action.

Diflubenzuron inhibits chitin synthesis, disrupts the mating processes of insect larvae, impedes their development, causes the death at immature stages and thus decreases mite populations.

The purpose of this study was the control of the repellent and acaricidal efficacy of the Demoged-Forte pharmaceutical product in the control of ectoparasites in cats and dogs, conditioned by the company Euro Prime Pharmaceuticals SRL and registered in the Republic of Moldova (Certificate of registration in the Republic of Moldova no.2904 of 23.01.17).

Materials and methods. The acaricidal impact of Demoged-Forte product was tested on dogs and cats at the veterinary clinic "ESCULAP" in Chisinau municipality, on groups of animals in the private sector in Gradiște, Cimișlia district. The research was carried out between July 2016 and August 2017. In accordance with the European Convention on the Protection of Experimental 
Animals, all animals were maintained under standard conditions and an optimal habitat was ensured for them $[5,8,11]$.

In order to determine the therapeutic efficacy of the Demoged-Forte product, 12 animals from the canine and feline species were selected (tab.).

The diagnosis of demodicosis was established based on clinical manifestations, considering the age of the animal, the characteristic of the skin lesions and the microscopic investigations of the deep scrapings of the affected skin $[7,9,11]$.

In sarcoptosis the diagnosis was established based on the clinical signs: spontaneous pruritus, changes caused by scratches, the presence of scabious buttons and the microscopic examination that revealed parasites in the deeply harvested scrap from the periphery of the affected areas $[2,12]$.

Table

Characteristics of the groups of animals studied

\begin{tabular}{|l|c|c|c|c|c|c|}
\hline $\begin{array}{c}\text { Animal species } \\
\text { and breed }\end{array}$ & $\begin{array}{c}\text { Nr.of } \\
\text { animals }\end{array}$ & Body mass, kg & $\begin{array}{c}\text { Age, } \\
\text { years }\end{array}$ & $\begin{array}{c}\text { Dose, ml for } \\
\text { animal }\end{array}$ & Diagnosis & $\begin{array}{c}\text { Duration of } \\
\text { treatment, days }\end{array}$ \\
\hline Half-breed dogs & 2 & $12 ; 11$ & 4,$1 ; 3,5$ & $0,5 \mathrm{ml} / \mathrm{kg} \mathrm{b.m.}$ & Demodicosis & 20 \\
\hline $\begin{array}{l}\text { Cats: } \\
\text { - half-breed } \\
\text { - persian }\end{array}$ & 2 & 4,$0 ; 4,3$ & 2,$8 ; 3,0$ & $0,5 \mathrm{ml} / \mathrm{kg} \mathrm{b.m.}$ & Notoendrosis & 10 \\
\hline Half-breed dogs & 2 & 9,$1 ; 10,5$ & 2,$6 ; 3,0$ & $3-5$ drops & Otodectosis & 12 \\
\hline Cats & 2 & 3,$5 ; 4,0$ & 2,$5 ; 2,0$ & $3-5$ drops & Otodectosis & 10 \\
\hline $\begin{array}{l}\text { Dogs: } \\
\text {-half breed } \\
\text {-terrier }\end{array}$ & 2 & $12 ; 13$ & 3,$0 ; 2,5$ & $0,5 \mathrm{ml} / \mathrm{kg} \mathrm{b.m.}$ & Sarcoptosis & 12 \\
\hline
\end{tabular}

What is specific for establishing the clinical diagnosis in notoedrosis is the localization on the head and the extension in the neighboring areas, the contagiousness and the intense itching. In the laboratory, the scrapings were examined microscopically after clarification and the parasites were highlighted.

For the diagnosis of otodectosis, the inner face of the ear flag was examined, where the presence of the sticky and abundant cerumen, thick scabs and grating lesions was established. Microscopic examination of the crusts revealed the presence of parasites [2, 12].

Treating the animals with Demoged-Forte, an external solution, was carried out by both veterinarians and pet owners, its personnel being previously trained by the veterinary surgeon.

Results and discussions. Analyzing the results of the tests noted in table 1, we can mention that the administration of the Demoged-Forte product, which is an external solution, in the form of drops on affected surfaces or in the external auditory canal lasted from case to case, from 15 to 45 days. The combination of fipronil and diflubenzuron, plus the presence of diphenhydramine (dimedrol), in the composition of the preparation Demoged-Forte, produced by the company Euro Prime Farmaceuticals SRL, is very effective in combating sarcoptosis and notoendrosis in dogs and cats. No signs of poisoning, adverse reactions, local skin irritation were observed at the animals taken for the study of the efficacy of the above mentioned preparation.

During the research, all animals were active, consumed water and food within the limits of physiological norms. After applying the Demoged-Forte product on the animal skin, it penetrates into the areas of localization of parasites, diminishes the inflammatory process and regenerates the affected tissues. It has no toxic action on the host animals, as it is absorbed through the skin in a reduced proportion of about $16 \%$ and diminishes relatively quickly by hydrolysis. The main route of excretion of fipronil is through feces $(75 \%)$ and a small part is eliminated through urine. In one month time, the treated animals were not showing any causal agents of sarcoptoosis and notoendrosis under laboratory circumstances. The alopecia area decreased by $82 \%$. Similar results were obtained by other researchers. 
The causative agent of otodectosis - O. cynotis, with its variations in dogs and cats causes severe irritation and the formation of red-brown bark inside the ear flag. The respective parasite can also be detected in the neck, in the sacral region and in the tail. These mites can attach themselves to fleas, which carry them to another animal. Demoged-Forte based on fipronil was also used to treat otodectosis, and results have shown it to be $99 \%$ effective. The efficacy of the preparation in the treatment of demodecal diarrhea has been confirmed in young dogs from 5 to 12 months. For the dogs treated by us, demodecosis evolved in a dry form mainly located periocularly, on the cheeks and the corner of the lips, on the ventral area of the neck. Symptomatic in the tested animals were highlighted: erythema, depilation and keratogenesis disorders. In order to obtain a positive result in the treatment with Demoged-Forte, we needed 2-5 consecutive administrations of the product. The treatment for dry demodicosis lasted from 2 to 7 weeks.

In all cases the treatment led to the complete disappearance of the clinical signs of the parasites in the skin scrapes, however, it is necessary to mention that the number of administrations varies and depends on the severity of the disease and the general condition of the animal.

\title{
C O N C L U S I O N
}

We consider that Demoged-Forte product, an external pest control solution, conditioned at Euro Prime Pharmaceuts SRL, independently, without complex therapy, has shown a high efficacy in the treatment of sarcoptosis, notoendrosis, otodectosis and demodecosis, which varies between 92$99 \%$, a fact that confirms that we can treat animals without endangering their lives.

\section{ВЕТЕРИНАРНИЙ ЛІКАРСЬКИЙ ЗАСІБ ”DEМОGЕD-FORTE,, У БОРОТЬБІ 3 ЕКТОПАРАЗИТОЗАМИ У СОБАК ТА КОТІВ}

\author{
Енчу Валерій \\ Державний аграрний університет Молдови, \\ вул. Мірчєшть, 42, м. Кишинів, MD 2049, Молдова
}

\section{А Н О Т А Ц I Я}

Паразитичні арахнози, з їхньою серйозною еволюцією, мають характер антропонотики 3 економічними, санітарними та соціальними наслідками. Зараження арахнозами значно знижує якість життя домашніх тварин. Він викликає захворювання обміну речовин, подряпини, алергічний стрес і призводить до розвитку бактеріальних дерматозів.

Фіпроніл - це довготривалий акарицидний та стійкий засіб. Метою цього дослідження було моніторинг ефективності акарициду фармацевтичного продукту Demoged-Forte для боротьби з ектопаразитами у собак та котів, за умовами, що надає компанія Euro Prime Farmaceuticals LLC. та котів.

Продукт дуже ефективний в боротьбі з саркоптозом та нотоендрозом (98-100 \%) у собак

При лікуванні отодектозу препарат виявив ефективність 99\%, а при демодекозі виявлено результат приблизно 90-92\%.

Таким чином, Demoged-Forte, незалежно, від комплексної терапії, показав високу ефективність у лікуванні саркоптоозу, нотоендрозу, отодектозу та демодекозу, між 92\%-99\%, що підтверджує, що ми можемо лікувати тварин, не загрожуючи їхньому життю.

Ключові слова: АРАХНОЗИ, ФІПРОНІЛ, ДИФЛУБЕНЗУРОН, ТЕСТУВАННЯ, ЛІКУВАННЯ, ЕФЕКТИВНІСТЬ. 


\title{
ВЕТЕРИНАРНОЕ ЛЕКАРСТВЕННОЕ СРЕДСТВО ”DEMOGЕD-FORTЕ,, В БОРЬБЕ С ЭКТОПАРАЗИТОЗАМИ У СОБАК И КОТОВ
}

\author{
Энчу Валерий \\ ${ }^{5}$ Государственный аграрный университет Молдовы. \\ ул Мирчешть, 42, г. Кишинев, MD 2049 Молдова,
}

\section{А Н Н О Т А ЦИ Я}

Паразитические арахнозы, с их серьезной эволюцией, имеют характер антропонотикы с экономическими, санитарными и социальными последствиями. Заражение арахнозамы значительно снижает качество жизни домашних животных. Он вызывает заболевание обмена веществ, царапины, аллергический стресс и приводит к развитию бактериальных дерматозов. Фипронил - это длительный акарицидный и устойчивый средство. Целью этого исследования было мониторинг эффективности акарицида лекарственного препарата Demoged-Forte для борьбы с эктопаразитами у собак и кошек, при условии, что предоставляет компания Euro Prime Farmaceuticals LLC.

Продукт очень эффективный в борьбе с саркоптозом и нотоендрозом (98-100 \%) у собак и кошек.

При лечении отодектоза препарат обнаружил эффективность 99 \%, а при демодекозе обнаружено результат примерно 90-92 \%.

Таким образом, Demoged-Forte, независимо от комплексной терапии, показал высокую эффективность в лечении саркоптоозу, нотоендрозу, отодектозу и демодекоза, между 92\% 99\%, что подтверждает, что мы можем лечить животных, не угрожая их жизни.

Ключевые слова: АРАХНОЗЫ, ФИПРОНИЛ, ДИФЛУБЕНЗУРОН, ИСПЫТАНИЯ, ЛЕЧЕНИЕ, ЭФФЕКТИВНОСТЬ.

\section{R E F E R E N C E S}

1. Bourdean P. Variation in size in Demodex canis: from the longest to the shortest forms //Veterinary Dermatologi, 2010, p. 213.

2. Curtis C. F. Current trends in the treatment of Sarcoptes, Cheyletiella and Otodectes mite infestations in dogs and cats //Veterinary Dermatology. 2004, 15, p. 108-114.

3. Enciu V. et al. Efectiveness of Ivermectiged 1\% to some ecto-and endoparasitosis in sheep. Sustainable use, protection of animal world and forest management in the context of climate change //IX - th international conference of zoologists. Chișinău, 2016, p. 125-126.

4. Erhan D., Chihai O., Rusu Ş. et. al. Index of the impact and the convalescence of the antiparasitic chemotherapy (Avomec 1\%, 2.5\% Rombendazol, Tylosinum 200) at infected cattles (S.papillosus, D.lanceolatum). Bulletin of University of Agricultural Sciences and Veterinary Medicine Cluj-Napoca. 2010.- Vol. 67 (2), p. 70-73.

5. European Convention for the Protection of Vertebrate Animals Used for Experimental and other Scientific Purposes (ETS 123). Strasburg, 1986.

6. Furie I. I. et al. Comparative eficacy and safety of two tretment regimens with a topically combination of imidacloprid and moxidectin (Advocate) againest generalized demodicosis //Parazitol. Res., 2009, p.15-24.

7. Mueller R. S. Tratament protocols for demodicosis: an evidence based review //Veterinary Dermatology, 2004, v. 15, p. 75-89. 
8. Paterson T. E. et al. Tratament of canine generalized demodicosis: a blind, randomized clinical trial comparing the efficacy of Advocate Bayer wiht ivermectin. //Veterinary Dermatology, 2009, v. 20, nr.5-6, p. 47-55.

9. Belova C. Demodecoz u sobak - Demodicosis caninum // VetPharma, 2011, № 5-6, c. 28-33. (in Russian).

10. Glazunov Yu. V., Stolbova O. A. Effektivnost insecto-akaritsidnysh preparatov veterinarno-sanitarnogo nadzora // Vestnik veterinarii.- 2014, № 2 (69), c. 26-29. (in Russian).

11. Kolesnikova N. A. Effectivnye skhemy lechenia devodekoza // VetPharma, 2012, №31, c. 56-58. (in Russian).

12. Ralf C/ Muller. Sarktoptoz, demodekoz i otodektoz u sobak: sposoby lechenia // Jurnal of Small Animal Practice. Российское издание, 2012, том. 3, № 1, с. 50-52. (in Russian).

Рецензент - О. Л. Тішин, д. вет. н., ДНДКІ ветпрепаратів та кормових добавок. 